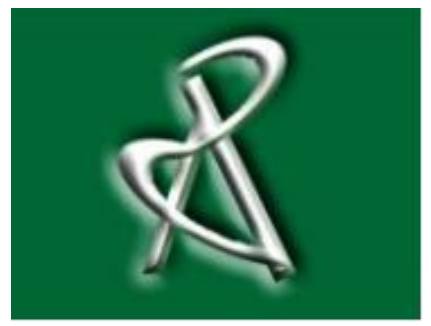

\section{Academic @ Paper \\ ISSN 2146-9067}

International Journal of Automotive

Engineering and Technologies

Vol. 5, Issue 2, pp. $25-37,2016$
International Journal of Automotive

Engineering and Technologies

http://www.academicpaper.org index.php/IJAET

\title{
Effect of mixing chamber or carburetor type on the performance of diesel engine operated on biodiesel and producer gas induction
}

\author{
V.S. Yaliwal ${ }^{1 *}$, N.R. Banapurmath ${ }^{2}$, Sachin Revenakar ${ }^{3}$, P.G. Tewari ${ }^{4}$ \\ ${ }^{1}$ SDM College of Engineering and Technology, Dharwad, Karnataka, India \\ ${ }^{2}$ BVB College of Engineering and Technology, Hubli, Karnataka, India \\ ${ }^{3}$ Graduate Trainee Engineer, Aequs Pvt Ltd, Belgaum \\ ${ }^{4}$ BVB College of Engineering and Technology, Hubli, Karnataka, India
}

Received 18 February 2016 Accepted 05 May 2016

\begin{abstract}
Biodiesel-producer gas fueled dual fuel engine suffers from lower brake thermal efficiency (BTE) with higher unburned hydrocarbon ( $\mathrm{HC}$ ) and carbon monoxide (CO) emissions at all loads. In this present work, to harness energy from producer gas and ensure air and producer gas mixing quality, different mixing chambers (carburetors) have been developed. In the first phase of the work, mixing chambers were analyzed for its mixing performance using experimental approach. Different carburetors were drawn from $\mathrm{Y}$ - shape having $45,60,90^{\circ}$ gas entries as well as with parallel flow gas entry. Based on the results obtained, it was found that parallel flow gas entry carburetor resulted in better mixing of air and producer gas. In the next phase of the work, experimental investigations were conducted to study the effect of air-producer gas mixture quality on the performance, combustion and emission characteristics of single cylinder, four strokes direct injection diesel engine developing $3.7 \mathrm{~kW}$ at 1500 rpm operated on dual fuel mode with Honge oil methyl ester (HOME) and producer gas induction. Experimental investigation showed that all carburetors except parallel flow gas entry carburetor resulted in lower performance. Dual fuel engine with parallel flow gas entry carburetor showed 5 to $8 \%$ increased BTE with reduced smoke, $\mathrm{HC}$ and $\mathrm{CO}$ emission levels compared to other carburetors tested. Based on the study, it is concluded that this area still requires more research with long term engine operation.
\end{abstract}

Key Words: Honge oil Methyl ester, Biomass gasification, Producer gas, Mixing chamber, Emissions, Sustainability, energy security

doi: 10.18245/ijaet.02009

*Corresponding Author:

Tel. : : +919242896639

E-mail : vsyaliwal2000@rediffmail.com 


\section{Introduction}

Increasing cost of electricity is a key issue for India and is same for rest of the world. This factor has created lot of attention for researchers. The main reason for this is due to growing population with increasing life quality, government policies and development of new technologies in engines. The harmful effects on human health caused by the degradation of environment due to emission of greenhouse gas (GHG) emissions, decreasing reserve of crude petroleum in the earth crust, and increasing cost of crude oil have been realized in the present energy scenario. In addition, India is now experiencing high and volatile energy prices as well as issues of national security against energy. Therefore, the need for sustainable and environmentally benign sources of energy for power generation and industrial growth has become necessary in recent years. In this regard, researchers are putting their sincere efforts on the engine research using alternative fuels. In this direction researchers have identified biomass as a main future fuel for energy applications. Researchers have estimated that about 620 million tonnes of biomass reserve in the country during 2004-2005 and was 700 million tonnes during 2010-2011. In addition, it may increase to 1200 million tonnes during end of 2025. India is producing about 450-500 million tonnes of biomass per year including sugarcane, bagasse and leaves. Biomass provides $32 \%$ of all the primary energy use in the country at present. About half of the surplus residues are burnt in the fields causing serious air pollution. The potential for additional generation of woody biomass in the country has been estimated to be about 255 million tonne. Out of this, forest wastelands are estimated to contribute 171 million tonne and the marginal crop land to contribute the remaining 84 million tons. Even though, India is still dependent on noncommercial fuel sources such as cow dung, firewood, agricultural waste and biofuels to the extent of $30-35 \%$. India had planned to produce 288 metric tonnes of biodiesel by the end of 2012, which was supplemented about
$41.14 \%$ of the total demand of diesel fuel consumption [1, 2, 3, 4, and 5].

In this context, researchers have reported effect of biodiesel properties on the performance and emission characteristics of diesel engine $[6,7]$. India has implemented many facilitating policies and programmes on biomass gasifier-based power units with as high as megawatt-level grid-connected plants that operate on a dual-fuel mode and $100 \%$ producer gas-run engines [5]. Dualfuelling of a diesel engine needs liquid fuel for initiating the combustion because the producer gas will not ignite under the prevailing conditions of temperature and pressure. In addition, dual fueling offers fuel flexibility, 70-90\% fuel saving, lowers emissions, acceptable efficiency and easy conversion of existing diesel engines. Several investigators have reported that use of advanced injection timing, increased compression ratio (CR) and addition of hydrogen resulted in increased thermal efficiency [8, 9, 10, and 11]. Reduced brakespecific fuel consumption, BTE and HC and $\mathrm{CO}$ emission levels have been reported in previous literatures [9, 10, and 12]. Power generation using biomass gasifier based projects and financial evaluation has been reported $[13,14]$. Several investigators have extensively investigated gasifier - engine systems for rural and urban power generation and agricultural applications [9, 12-17]. Dual fuel operation with producer gas favors higher compression ratio as it has high octane number and self-ignition temperature, but it suffers from $20-30 \%$ power derating $[10,11]$. Many researchers have generated producer gas using biomass feedstock of different origin and investigated performance and emission characteristics of diesel engine operated on diesel/biodiesel and producer gas combinations [10-12, 15, and 18]. In the case of a producer gas-fuelled dual-fuel engine, the performance was found to be lower than as acceptable. This could be due to improper air-producer gas mixing, hence a suitable mixing chamber or carburetor must be designed. Shridhar et al 2005 have developed a carburetor for producer gas fueled engine 
(Spark ignited engine). A suitable mixing chamber provides a mixture of appropriate predefined air-to-fuel ratios to the engine over the entire range of engine operation [9, $11]$.

Major attention and interest is given to enhance the thermal efficiency of a producer gas-operated dual-fuel engine with decreased emission levels. The use of biodiesel and producer gas-based power generation will create new industries, addresses energy security and bring increased economic activity. In this context, the present study aims to develop various mixing chambers and investigation of mixing performance through experiments. Further, the present study was extended to investigate the performance combustion and emission characteristics of a water-cooled, singlecylinder, direct injection (DI) compression ignition $(\mathrm{CI})$ engine operated under a dualfuel mode with HOME and producer gas induction. Further, the results were compared with diesel-producer gas operation.

\section{Producer gas supply system}

Ensuring uniform supply of quality gas and stoichiometric air-producer gas mixture to the dual fueled engine is quite difficult as this would depend on the gasifier design and operating conditions, mechanism of reactions taking place and flow conditions occurring through the gasifier system. Carburetor used for mixing air and producer gas mainly consists of individual fluid inlets with single outlet, which is attached to the intake manifold of an engine. Carburetor developed must have an ability to maintain the required air-fuel ratio (1.2 to 1.3) with varying load and pulsating gas flow conditions [12, 19, 20]. The carburetor was developed to operate in conjunction with a calibrated venturimeter designed for the producer gas flow measurement. Figure 1 shows the producer gas supply system with Y -shaped carburetor, venturimeter and digital gas flow meter. During the engine operation, appropriate mixture of producer gas and air were supplied to the engine. The supply of producer gas was adjusted manually to obtain maximum substitution of producer gas. The air and producer gas flow rates were measured individually over a range of engine operating conditions. The air-producer gas (A/F) ratio was reasonably constant beyond a specified mixture flow rate, with relatively rich mixture at low flow rates. Rich mixture for engine start-up and no-load operations and relatively leaner mixture during part load operations [12, 20, and 21].

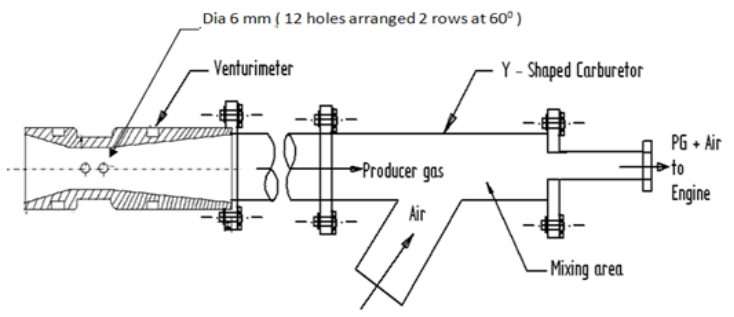

Fig. 1 Schematic diagram of producer gas supply system with $\mathrm{Y}$ - shaped carburetor

\section{Characterization of fuels used}

HOME was derived from Honge seeds and producer gas by partial combustion of woody biomass in a down draft gasifier. Producer gas composition involves $\mathrm{CO}, \mathrm{H}_{2}, \mathrm{CO}_{2}$, Nitrogen and Methane. The laminar burning velocity for producer gas (at $0.1 \mathrm{MPa}, 300 \mathrm{~K}$ ) was about $0.5 \mathrm{~m} / \mathrm{s}$, which is about $30 \%$ higher than methane [9]. The properties of the fuels were determined in the laboratory. Table 1 shows the properties of liquid fuels and proximate and ultimate analysis of biomass feed stock used in the present study. Composition of producer gas derived from babul wood was checked two times at different timings during the test and averaged out values are shown in Table 2.

\section{Experimental setup}

Experimental investigations were conducted on four-stroke, single cylinder, direct injection water cooled compression ignition engine as shown in Figure 2 (a) and (b). The specification of the gasifier- engine system is given in Table 3 . The engine was always operated at a rated speed of $1500 \mathrm{rev} / \mathrm{min}$. The engine had conventional fuel injection system. The injection nozzle had three holes of $0.3 \mathrm{~mm}$ diameter with a spray angle of $120^{\circ}$. The injector opening pressure and the static injection timing as specified by the 
engine manufacturer for diesel operation were 205 bar and $23^{0}$ before top dead centre (bTDC), respectively. However, for the present study, the injection timing and injection pressures of $27^{\circ} \mathrm{bTDC}$ and $230 \mathrm{bar}$ were used with dual fuel operation as these were optimized in the earlier work reported by authors [9-11]. The engine is provided with a hemispherical combustion chamber with overhead valves operated through push rods. The engine was cooled by circulating water through the jackets of the engine block and cylinder head. In this present work, the air and producer gas flow rates were measured using air box method and venturimeter connected with digital indicator respectively. Roussos et al., [21] reported fuel-air equivalence ratio and its effect on the for dual fuel operation.

Figures 3, 4, 5 and 6 shows $\mathrm{Y}$ - shaped, $60^{\circ}$, $90^{\circ}$ and parallel flow gas entry carburetors. The cylinder pressure was measured with piezo electric transducer fitted in the cylinder head. Exhaust gas analyzer and Hartridge smoke meter were used to measure $\mathrm{HC}, \mathrm{CO}$, $\mathrm{CO}_{2}, \mathrm{NO}_{\mathrm{X}}$ and smoke emissions. All the readings were repeated for five times and average readings were used for analysis.

Table 1 Properties of liquid fuels and Proximate and ultimate analysis of biomass feed stocks

\begin{tabular}{llllllllll}
\hline $\begin{array}{l}\text { Type of } \\
\text { wood }\end{array}$ & $\begin{array}{l}\mathrm{CO} \\
\%\end{array}$ & $\begin{array}{l}\mathrm{H}_{2} \\
\%\end{array}$ & $\begin{array}{l}\text { Metha } \\
\text { ne }\end{array}$ & $\begin{array}{l}\mathrm{HC} \\
\%\end{array}$ & $\begin{array}{l}\mathrm{N}_{2} \\
\%\end{array}$ & $\begin{array}{l}\text { Water } \\
\text { Vapour } \\
\%\end{array}$ & $\begin{array}{l}\mathrm{CO}_{2} \\
\%\end{array}$ & $\begin{array}{l}\text { Calorific } \\
\text { value } \\
\mathrm{kJ} / \mathrm{m}^{3}\end{array}$ & $\begin{array}{l}\text { Density } \\
\mathrm{kg} / \mathrm{m}^{3}\end{array}$ \\
\hline $\begin{array}{l}\text { Babul } \\
\text { wood }\end{array}$ & $\begin{array}{l}18- \\
22 \%\end{array}$ & $\begin{array}{l}15- \\
19 \%\end{array}$ & $1-5 \%$ & $\begin{array}{l}0.2- \\
0.4 \%\end{array}$ & $\begin{array}{l}4.5- \\
5.5 \%\end{array}$ & 4 & $8-10 \%$ & 5200 & 360 \\
\hline
\end{tabular}

Table 2 Composition of producer gas

\begin{tabular}{clcclc}
\hline S.N & \multicolumn{1}{c}{ Properties } & Diesel & HOME & Description & Babul wood \\
\hline 1 & Viscosity @ 40 ${ }^{0} \mathrm{C}$ (cst) & 4.59 (Low) & 5.6 & Moisture Content, \% wlw & 10.3 \\
2 & Flash point ${ }^{0} \mathrm{C}$ & 56 & 163 & Ash Content, \% wlw & 0.79 \\
3 & Calorific value in kJ / kg & 45000 & 36,010 & Volatile Matter, \% wlw & 85.8 \\
4 & Specific gravity & 0.830 & 0.870 & Fixed Carbon \% wlw & 13.4 \\
5 & Density Kg / m3 & 830 & 890 & Sulphur, \% wlw & 0.05 \\
6 & Type of oil & Fossil & Non edible & Nitrogen, as N \% wlw & 0.30 \\
7 & ------ & ----- & Gross Calorific value, Cal/g & 5631.0 \\
8 & ----- & ---- & --- & Gross Calorific value, $\mathrm{kJ} / \mathrm{kg}$ & 23575.8 \\
9 & ----- & ----- & Density, kg/ $\mathrm{m}^{3}$ & 380 \\
10 & --------- & Phosphorus \% w/w & -- \\
\hline
\end{tabular}

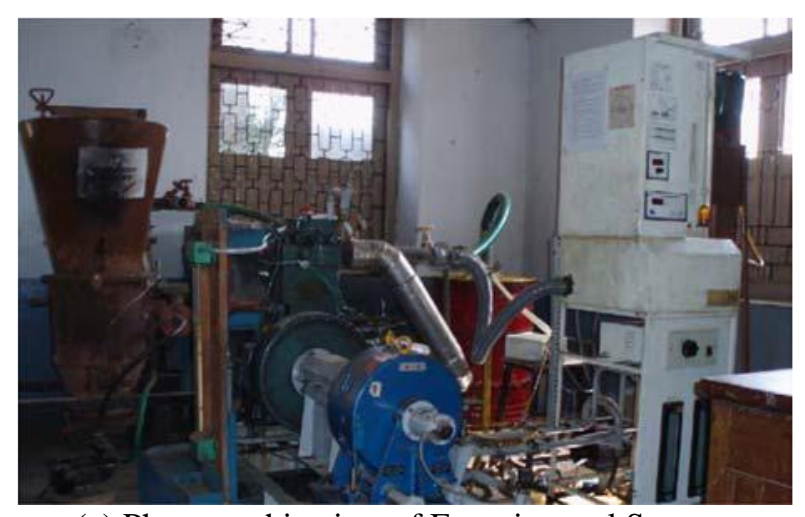

(a) Photographic view of Experimental Setup

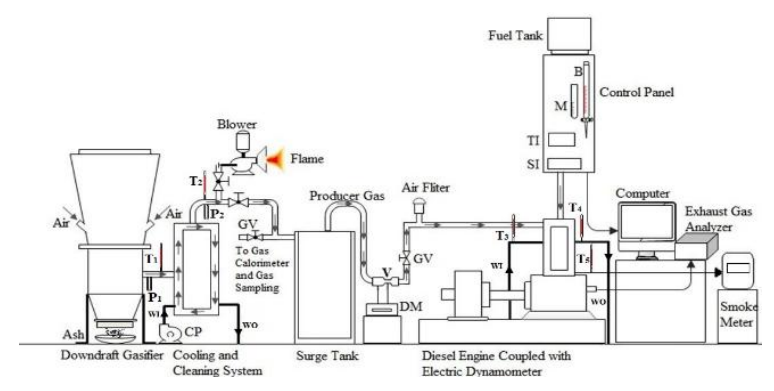

(b) Schematic diagram of Experimental Setup

Fig. 2 Overall view of Experimental Setup

\section{Results and discussions}

Experimental investigations have been conducted in two phases. In the first phase of the work, air-producer gas mixing performance has been studied and better carburetor type for dual fuel operation was identified. In the phase of the present work, effect of air-producer gas mixture quality on the performance, combustion and emission 
characteristics have been carried out using different mixing chambers or carburetors. Further, the results obtained with HOME- producer gas combination were compared with diesel-producer gas operation.

Table 3 Shows specification of experimental test rig and down draft gasifier

\begin{tabular}{|c|c|c|c|c|}
\hline \multirow{2}{*}{$\mathbf{S N}$} & \multicolumn{2}{|c|}{ Compression ignition engine } & \multicolumn{2}{|c|}{ Down draft gasifier } \\
\hline & Parameters & Specification & Parameters & Specification \\
\hline 1 & Machine Supplier & $\begin{array}{l}\text { Apex Innovations Pvt Ltd, Sangli. } \\
\text { Maharastra State. }\end{array}$ & Rated capacity & $15000 \mathrm{kcal} / \mathrm{hr}$ \\
\hline 2 & Engine Type & $\begin{array}{l}\text { Single cylinder four stroke water cooled } \\
\text { direct injection TV1 compression } \\
\text { ignition engine with a displacement } \\
\text { volume of } 662 \mathrm{cc} \text {, compression ratio of } \\
17: 1 \text {, developing } 5.2 \mathrm{~kW} \text { at } 1500 \mathrm{rev} / \mathrm{min} \\
\text { TV1 ( Kirolsker make) }\end{array}$ & Rated gas flow & $15 \mathrm{Nm}^{3} / \mathrm{hr}$ \\
\hline 3 & Software used & Engine Soft & $\begin{array}{l}\text { Average gas } \\
\text { calorific value }\end{array}$ & $1000 \mathrm{kcal} / \mathrm{m}^{3}$ \\
\hline 4 & $\begin{array}{l}\text { Nozzle opening } \\
\text { pressure }\end{array}$ & $200-225$ bar & $\begin{array}{l}\text { Rated woody } \\
\text { biomass } \\
\text { consumption }\end{array}$ & $5-6 \mathrm{~kg} / \mathrm{hr}$ \\
\hline 5 & Governor type & Mechanical centrifugal type & Hopper capacity & $40 \mathrm{~kg}$ \\
\hline 6 & $\begin{array}{l}\text { Cylinder diameter } \\
\text { (Bore) }\end{array}$ & $0.0875 \mathrm{mtr}$ & Biomass size & $\begin{array}{l}\text { 10mm (Minimum) } \\
\text { 50mm (Maximum) }\end{array}$ \\
\hline 7 & Stroke length & $0.11 \mathrm{mtr}$ & $\begin{array}{l}\text { Moisture content } \\
\text { (DB) }\end{array}$ & 5 to $20 \%$ \\
\hline 8 & $\begin{array}{l}\text { Combustion } \\
\text { camber }\end{array}$ & $\begin{array}{l}\text { Open Chamber (Direct Injection) with } \\
\text { hemispherical cavity }\end{array}$ & $\begin{array}{l}\text { Typical } \\
\text { conversion } \\
\text { efficiency }\end{array}$ & $70-75 \%$ \\
\hline 9 & $\begin{array}{l}\text { Eddy current } \\
\text { dynamometer: }\end{array}$ & $\begin{array}{l}\text { Model :AG - 10, } 7.5 \mathrm{KW} \text { at } 1500 \text { to } \\
3000 \mathrm{RPM} \text { and Water flows through } \\
\text { dynamometer during the use }\end{array}$ & & \\
\hline
\end{tabular}
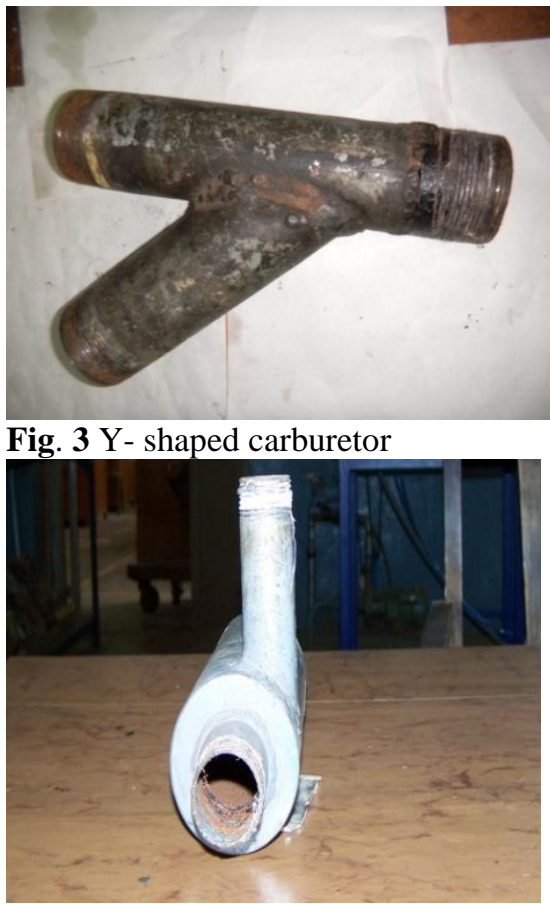

Fig. $590^{0}$ gas entry carburetor

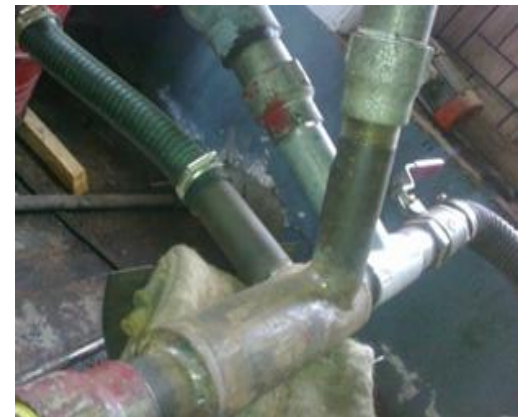

Fig. $460^{\circ}$ gas entry carburetor

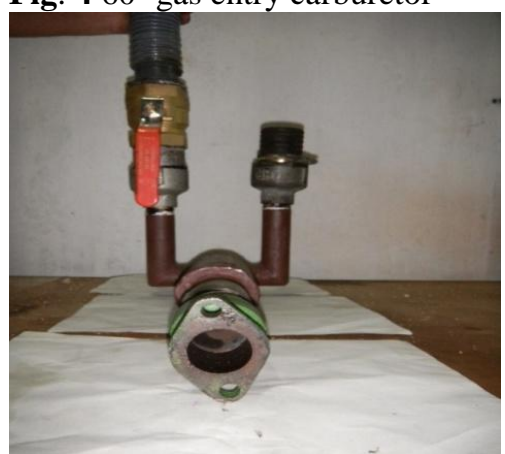

Fig. 6 Parallel flow gas entry carburetor 


\subsection{Optimization of carburetor for dual fuel operation: Experimental approach}

Figure 7 presents the fuel-air equivalence ratio obtained for different carburetor or mixing chambers. Reduced equivalence ratio has been obtained for Y-shape, $60^{\circ}$ and $90^{\circ}$ carburetor compared to parallel flow gas entry carburetor. Parallel flow gas entry carburetor resulted in better mixing performance. It could be due to better mixture of air and producer gas and turbulence. During the experimentation, it is observed that, the flow rate of producer gas was not constant. In addition, the fuel-air equivalence ratio was greatly affected by variation in gas flow rate and its composition. Hence minimum five reading were recorded at different timings and averaged out value was used for the analysis. Influencing factors such as variations in gas quality, improper gas flow rates and flow friction due to bends in the pipe lines significantly affect the airproducer gas mixing. Mixing chambers are developed in such a way that they should supply an air-producer gas mixture at an excess air ratio. However, flow rate of the airproducer gas mixture can be well controlled using an integrated mechanical valve. It is evident from the Figure 7 that the mixing chamber used in this present work provides an air-producer gas mixture quality based on its development. Frictional resistance and inadequate turbulence may be responsible for lower mixing performance with Y-shape, $60^{\circ}$ and $90^{\circ}$ carburetors. The air-producer gas equivalence ratio for $\mathrm{Y}$-shape, $60^{\circ}$ and $90^{\circ}$ carburetors were found to be $0.44,0.49$ and 0.58 compared to 0.62 for parallel flow gas entry carburetor.

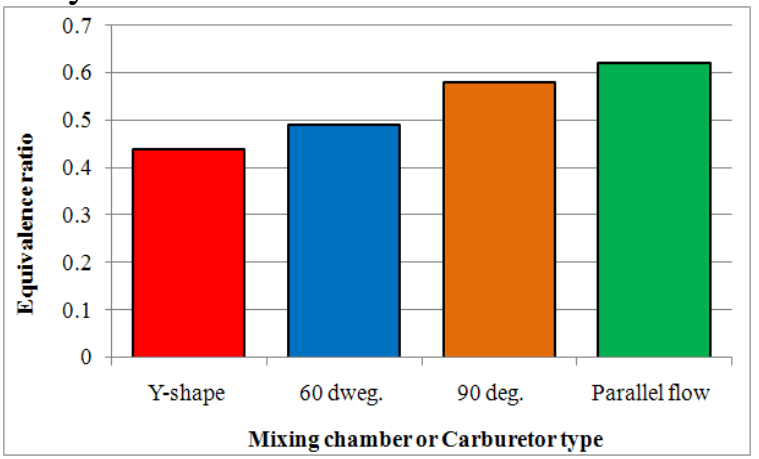

Fig. 7 Effect of carburetor design on the equivalence ratio

\section{3 Effect of mixing chamber type on the performance, combustion and emissions of dual fuel operation}

This section presents the effect of mixing chamber type on the overall performance of diesel engine operated on a dual fuel mode using HOME and producer gas induction. During the experimentation, the producer gas flow rate was maintained constant and engine speed was maintained at $1500 \mathrm{rpm}$. Injection timing of $27^{0} \mathrm{bTDC}$, injection pressure of 230 bar and compression ratio of 17.5 are maintained constant throughout the study. Results and discussions on the performance of dual fuel engine operated on HOMEproducer gas combination have been presented in subsequent paragraph.

\subsubsection{Performance characteristics}

The variation of BTE with various carburetors or mixing chambers at $80 \%$ engine load has been presented in Figure 8. The BTE was found to be higher for dieselproducer gas dual fuel mode of operation compared to HOME-producer gas operation. Producer gas being common, properties of the injected fuel has a major effect on the engine performance. The lower BTE with biodiesel injected fuel could be due to reduced equivalence ratio and higher viscosity which makes atomization difficult and lower adiabatic flame temperature of producer gas. However, the performance of HOME-producer gas operation can be improved to some extent if air-producer gas was mixed at nearly stoichiometric ratio. Of all the carburetors tested, parallel flow gas entry carburetor resulted in better performance compared with $\mathrm{Y}$ and $60^{\circ}$ and $90^{\circ}$ gas entry carburetors. This could be attributed to better turbulence and airproducer gas mixing. In addition, parallel flow gas entry carburetor provides a homogeneous mixture of air and producer gas and varying mixture flow according to load. The BTE values at $80 \%$ load with HOME - producer gas operation and $\mathrm{Y}, 60^{\circ}$, $90^{\circ}$ degree and parallel flow gas entry carburetors were found to be $13.65,14.41$, 15.25 and $16.18 \%$ and $20.25 \%$ for Diesel- 
producer gas operation with parallel flow gas entry carburetor respectively.

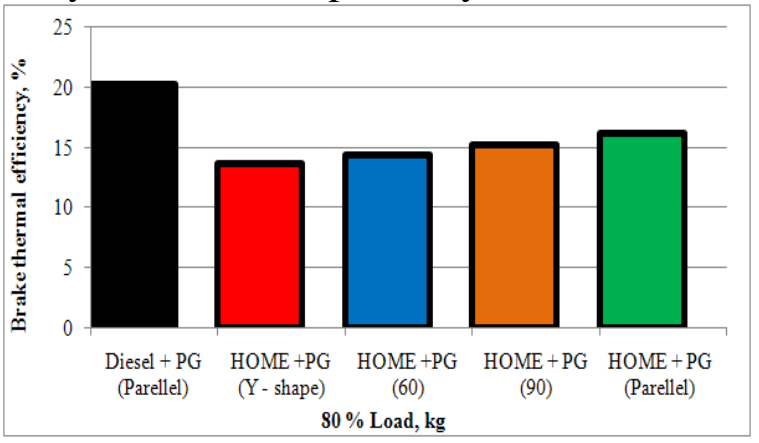

Fig. 8 Variation of BTE at $80 \%$ load

Exhaust gas temperature at $80 \%$ load during dual fuel mode of operation is presented in Figure 9. The Exhaust gas temperature was found to be higher for HOME-producer gas compared to Diesel-producer gas operation. This could be due to the incomplete combustion of gaseous fuel with the injected biodiesel inside combustion chamber with most of the fuel burning during expansion stroke. Results showed that the parallel flow gas entry carburetor gives lower exhaust gas temperature compared with other carburetors tested. Improved combustion caused by the better mixing of air-producer gas is responsible for this observed trend. However, air-producer gas was mixed nearly at stoichiometric when parallel flow gas entry carburetor was used. The exhaust gas temperature values at $80 \%$ load with $\mathrm{HOME}$ - producer gas operation and $\mathrm{Y}, 60^{\circ}, 90^{\circ}$ and parallel flow gas entry carburetors were found to be $540,525,510$ and $495^{\circ} \mathrm{C}$ and 385 ${ }^{\circ} \mathrm{C}$ for Diesel-producer gas operation with parallel flow gas entry carburetor respectively.

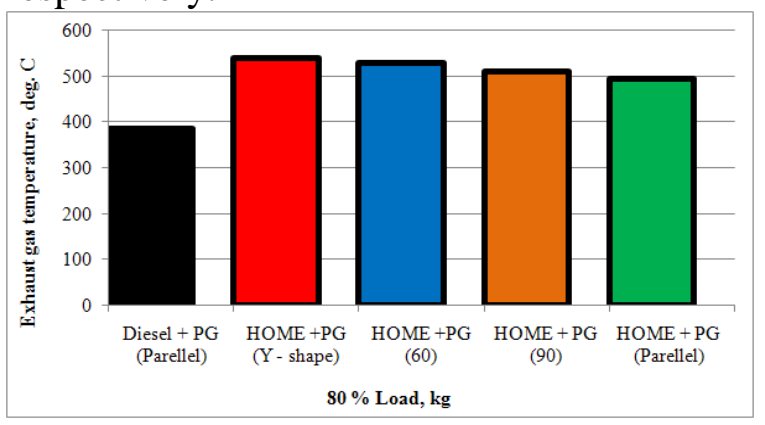

Fig. 9 Variation of EGT at $80 \%$ load

\subsubsection{Emission characteristics}

Emission Characteristics of engine are important as far as environmental aspect is concerned. The emission levels with producer gas operation under dual fuel mode were measured under steady state conditions, using well calibrated instruments. The different emission measurements for the dual fuel mode operation at $80 \%$ load are discussed below.

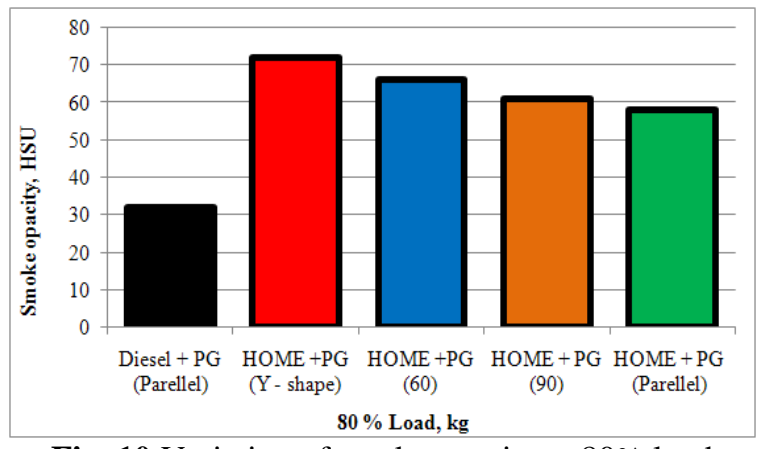

Fig. 10 Variation of smoke opacity at $80 \%$ load

Results related to smoke opacity at $80 \%$ engine load is presented in Figure 10. The smoke opacity was lower for diesel- Producer gas dual fuel operations compared to HOME - Producer gas over the entire load range. Improper air-fuel mixing rates due to presence of free fatty acid and heavier molecular structure of the injected bio-diesel compared to diesel resulted in higher smoke levels. Of all the carburetors, parallel flow gas entry gives lower smoke emissions compared to $\mathrm{Y}, 60^{\circ}$, and $90^{\circ}$ gas entry carburetors. The improved air and gas mixing in parallel gas entry carburetor as evident from CFD analysis (Figure 14) resulted into complete combustion of gaseous fuel. The smoke opacity values at $80 \%$ load with HOME - producer gas operation and Y, $60^{\circ}$, $90^{\circ}$ and parallel flow gas entry carburetors were found to be 72, 66, 61 and $58 \mathrm{HSU}$ and 32 HSU for Diesel -producer gas operation with parallel flow gas entry carburetor respectively.

The variation of $\mathrm{HC}$ emission levels at $80 \%$ load is shown in Figure 11. The lower BTE associated with bio-diesel compared to diesel, resulted into higher $\mathrm{HC}$ emissions with higher wall wetting observed in the former case. Parallel flow gas entry carburetor nearly ensures stoichiometric mixture of air and producer gas compared to other carburetors tested and this further supported by improved combustion. HC 
emissions were observed in the range of 65 to $73 \mathrm{ppm}$ for neat Diesel-producer gas operation and 46 to $64 \mathrm{ppm}$ for HOMEProducer gas dual fuel operation throughout the load range at the optimum parameters. At lower loads, HC level were found to be higher and decreased at higher loads. The HC emission values at $80 \%$ load with HOMEproducer gas operation and $\mathrm{Y}, 60^{\circ}, 90^{\circ}$ and parallel flow gas entry carburetors were found to be 69, 61, 58 and $54 \mathrm{ppm}$ and 38 ppm for Diesel-producer gas operation with parallel flow gas entry carburetor respectively.

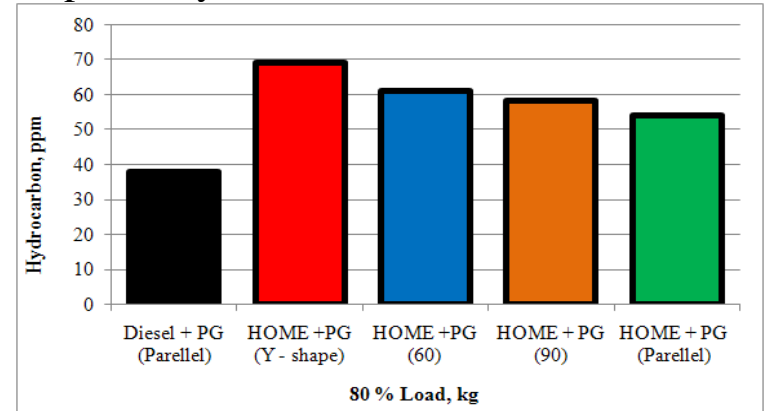

Fig. 11 Variation of $\mathrm{HC}$ emission at $80 \%$ load

The effect of brake power on $\mathrm{CO}$ emissions for Diesel-producer gas and HOMEproducer gas, dual fuel operation is shown in Figure 12. Higher concentration of $\mathrm{CO}$ in the exhaust is a clear indication of incomplete combustion of the pre-mixed mixture. The CO levels were higher for dual-fuel operation due to the presence of $\mathrm{CO}$ in the producer gas and combustion inefficiencies. It may also be due to the improper mixture of producer gasair flow to the engine with reduced amount of oxygen required for complete combustion and this provides incomplete combustion and increased $\mathrm{CO}$ emission levels. At lower loads, the mixture being leaner, results in greater extent of incomplete combustion and hence higher $\mathrm{CO}$ concentration. This puts a lower load limit for the dual fuel operation. At higher loads, the $\mathrm{CO}$ levels in the exhaust may slightly be reduced to lower extent compared to lower loads because of increased combustion temperature. Higher emission of $\mathrm{CO}$ levels in the exhaust could be attributed to lower heating value of producer gas, lower adiabatic flame temperature and lower mean effective pressures. However, the $\mathrm{CO}$ emission levels were found to be lower with parallel flow carburetor compared to other carburetors tested. This could be due to better mixing of gaseous fuel with air as is evident from the Figure 14 and leads to slightly improved combustion. The $\mathrm{CO}$ emission values at $80 \%$ load with HOMEproducer gas operation and $\mathrm{Y}, 60^{\circ}, 90^{\circ}$ and parallel flow gas entry carburetors were found to be $0.78 \%, 0.67 \%, 0.58 \%, 0.47 \%$ and $0.31 \%$ for Diesel-producer gas operation with parallel flow gas entry carburetor respectively.

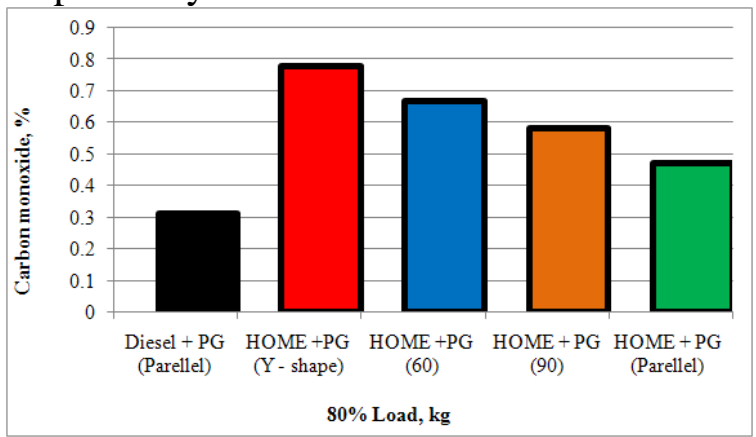

Fig. 12 Variation of $\mathrm{CO}$ emission at $80 \%$ load

Nitric oxide (NOx) emission levels for the tested fuel combinations at $80 \%$ engine load are presented in Figure 13. The NOx emissions were found to be higher for Dieselproducer gas dual fuel operations compared to HOME-producer gas over the entire load range. Diesel- producer gas operation resulted in higher BTE associated with higher NOx emissions as it is evident from higher heat release rate during premixed combustion as shown in Figure 26. Lower adiabatic flame temperature of producer gas and absence of organic nitrogen in producer gas could also be responsible for the observed trend. Results indicate that the parallel flow gas entry carburetor gives higher NOx compared with other carburetors tested because of higher heat release rates during premixed combustion. The NOx emission values at $80 \%$ load with HOME-producer gas operation and $\mathrm{Y}, 60^{\circ}, 90^{\circ}$ and parallel flow gas entry carburetors were found to be 61 ppm, 68 ppm, 74 ppm and 78 ppm and 110 ppm for Diesel-producer gas operation with parallel flow gas entry carburetor respectively. 


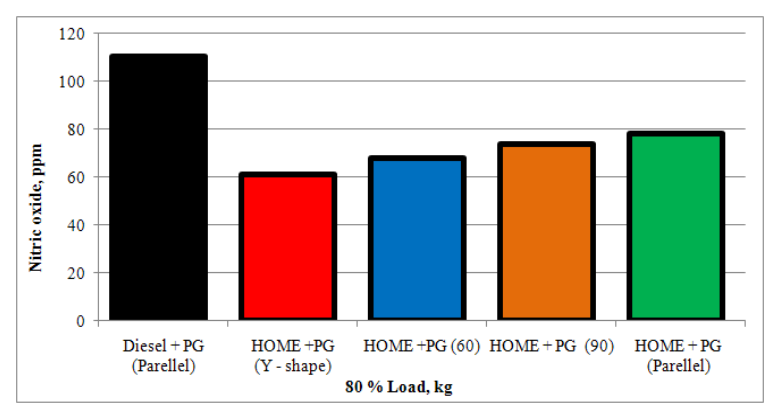

Fig. 13 Variation of NOx at $80 \%$ load

\subsubsection{Fuel substitution}

Figure 14 presents the fuel substitution for dual fuel operation at $80 \%$ load. Fuel substitution values were higher for Dieselproducer gas operation compared to HOMEproducer gas combinations. Injected fuel properties such as cetane number, viscosity and calorific value may be considered as responsible for the observed trend. Substitution was higher at lower loads and found to decrease with increased load. The fuel substitution at $80 \%$ load with HOMEproducer gas operation and $\mathrm{Y}, 60^{\circ}, 90^{\circ}$ and parallel flow gas entry carburetors were found to be $45 \%, 53 \%, 49 \%$ and $57 \%$ and $61 \%$ for Diesel-producer gas operation with parallel low gas entry carburetor respectively.

\subsubsection{Combustion analysis}

The combustion in a diesel engine differs when gaseous fuels are used and it depends on the air-fuel mixture quality. Different combustion characteristics are discussed below:

Variation of ignition delay with different carburetors at $80 \%$ load is shown in Figure 15.

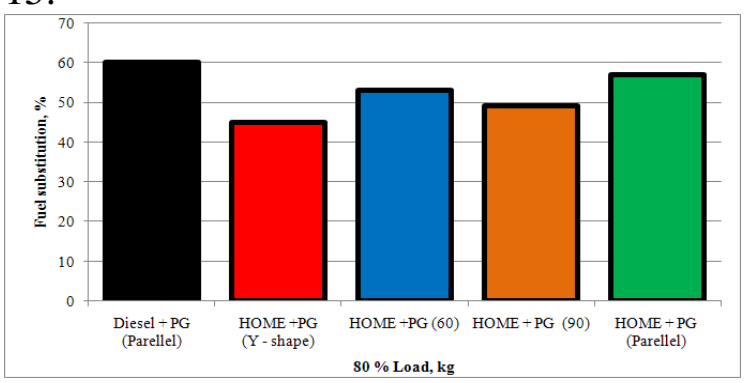

Fig 14 Variation of fuel substituted at $80 \%$ load

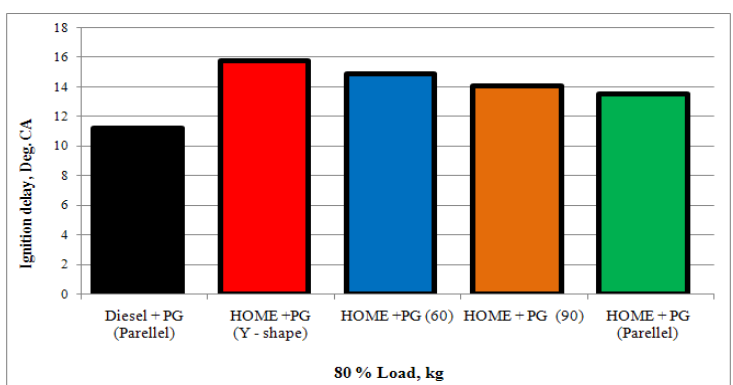

Fig. 15 Variation of ignition delay at $80 \%$ load

The ignition delay is calculated based on the static injection timing. Dual fuel operation with HOME-producer gas showed longer ignition delays compared to Diesel-producer gas operation. The injected fuel had the influence on the results indicated. Variations in the air-producer gas mixture in different carburetors lead to difference in the air-fuel ratio and improper burning of fuel with producer gas, which affects the combustion. Longer ignition delay was observed for HOME-producer gas operation and it is mainly because of improper mixing of fuel combination during ignition delay caused by higher viscosity and density and reduced volatility of HOME compared to diesel along with lower burning nature of producer gas. The HOME-producer gas (parallel flow gas entry carburetor) operation gives slightly lower ignition delay compared to HOMEproducer gas operation with other carburetors used. This is because parallel flow gas entry carburetor results in nearly stoichiometric mixture and it may be due to turbulent flow resulted in air and producer gas flow-pipes of the carburetor. Values of the ignition delay at $80 \%$ load were $19.82,18.93,18.01 \mathrm{deg}$. CA for HOME- producer gas (Y - shape), HOME-producer gas (60), HOME-producer gas (90) and HOME- producer gas (parallel flow gas entry) operation respectively, compared to $13.65^{\circ} \mathrm{CA}$ for Diesel-producer gas (parallel flow gas entry) operation at $80 \%$ load.

Variation of combustion duration with different carburetors at $80 \%$ load is shown in Figure 16. It was calculated based on the duration between the start of combustion and 90\% cumulative heat release. The combustion duration increases with increase in the power output with all the fuels. This is 
due to increase in the quantity of fuel injected. Higher combustion duration is observed with HOME-producer gas compared to Diesel-producer gas. It could be due to improper air-fuel mixing, longer time required for mixing and leading to incomplete combustion and longer diffusion combustion phase. However, from the Figure, it is observed that the combustion duration was reduced and improved with the HOME-producer gas (parallel flow gas entry) operation. This could be due to improper mixing of air-producer gas in the respective carburetor. Also reduced heat release rate was obtained with HOMEproducer gas $\left(\mathrm{Y}\right.$-shape, $\left.60^{\circ}, 90^{\circ}\right)$ and HOME- producer gas and (parallel flow gas entry) operation compared to dieselProducer gas dual fuel operation. This may also be due to higher viscosity of HOME and reduction of air-fuel mixing rates along with slow-burning producer gas. This leads to less fuel being prepared for rapid combustion with HOME-producer gas operation after the ignition delay. Therefore more burning occurs in the diffusion phase rather than in the premixed phase with HOME- producer gas operation. Significantly higher combustion rates during the later stages with HOME- Producer gas operation leads to higher exhaust temperatures and lower thermal efficiency. However, HOMEproducer gas (parallel flow gas entry) operation shows improvement in heat release rate compared to HOME-producer gas operation with other carburetors tested. Values of the combustion duration at $80 \%$ load were 53.65, 48.01, 45.12 and $40.15 \mathrm{deg}$. CA for HOME-producer gas (Y-shape), HOME-producer gas $\left(60^{\circ}\right)$, HOMEproducer gas $\left(90^{\circ}\right)$ and HOME-producer gas (parallel flow gas entry) operation respectively, compared to $36^{\circ} \mathrm{CA}$ for Dieselproducer gas (parallel flow gas entry) operation at $80 \%$ load.

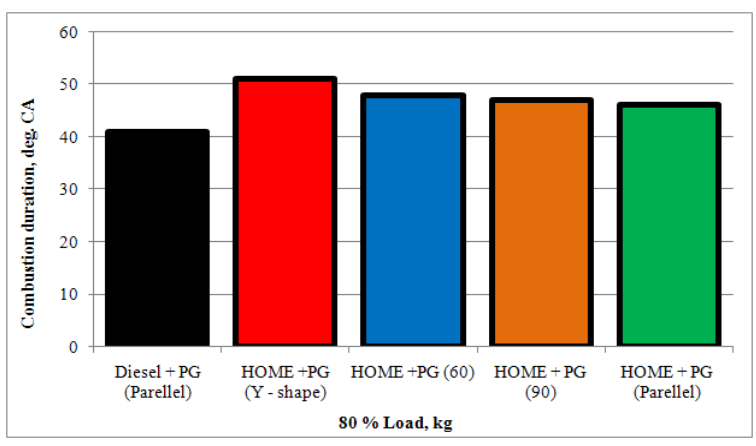

Fig. 16 Variation of combustion duration at $80 \%$ load

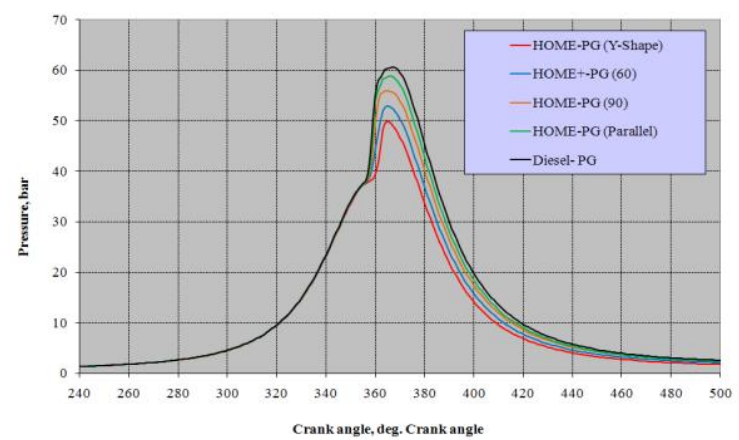

Fig. 17 In-cylinder pressure versus crank angle for HOME-producer gas combinations with different carburetor at $80 \%$ load.

Figure 17 shows in-cylinder pressure versus crank angle for different HOME-producer gas and Diesel-producer gas combinations at $80 \%$ load. The peak pressure depends on the combustion rate and the amount of fuel taking part in rapid combustion period. The uncontrolled combustion phase is governed by the ignition delay period and by the mixture preparation during the delay period. Therefore, mixture preparation and slow burning nature of producer gas during the ignition delay period were responsible for this trend of peak pressure and maximum rate of pressure rise. Results showed that dieselProducer gas results in higher peak pressure compared to HOME-producer gas with different carburetors. It may be due to higher viscosity and lower volatility of HOME. The lower peak pressure was observed for the HOME-producer gas (Y-shape, 60 $0^{\circ}, 90^{\circ}$ ) compared to HOME-producer gas (parallel flow gas entry) operation. Carburetor type influences the nature of the pressure crank angle variation.

Figure 18 shows rate of heat release versus crank angle for HOME-producer gas and Diesel - producer gas combinations at $80 \%$ load using different carburetors. Results 
showed that Diesel-producer gas results in higher heat release rate compared to HOMEproducer gas with different carburetors. It may be due to higher viscosity and lower volatility, cetane number and calorific value of HOME. The lower heat release rate was observed for the HOME-producer gas ( $\mathrm{Y}-$ shape, $60^{\circ}, 90^{\circ}$ ) compared to HOMEproducer gas (parallel flow gas entry) operation. Carburetor type influences the nature of the heat release rate.

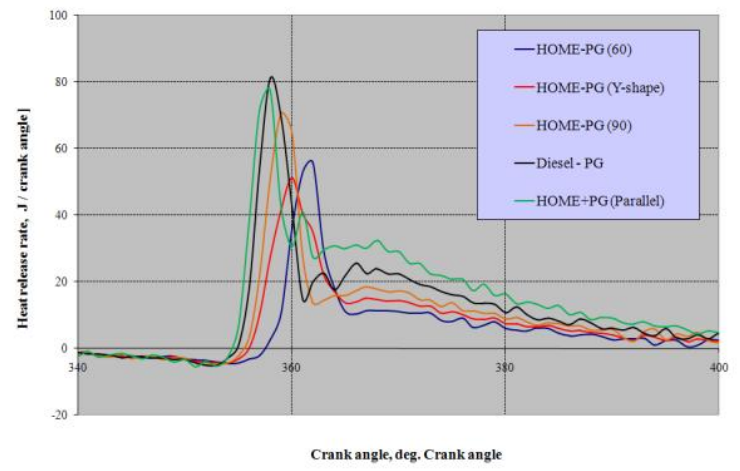

Fig. 18 Rate of heat release versus crank angle for HOME-producer gas combinations with different carburetor at $80 \%$ load

\section{Estimation of uncertainty}

Errors in all experimental data were bound to occur that ultimately affect the accuracy of measured value and also limit the conclusions of the present work. Random errors and systematic errors were minimized by the proper calibration of the measuring instruments. The uncertainties of different quantities were determined and were 1.95 , $14.56,8.65,6.28,14.28$ and $5.45 \%$ for BTE, EGT, smoke opacity, CO, NOx and fuel substitution, respectively.

\section{Conclusions}

The following conclusions are made from the present study.

D Experimental analysis using different carburetors showed that parallel flow gas entry carburetor resulted in better mixing performance compared to $\mathrm{Y}$-shape, $60^{\circ}$ and $90^{\circ}$ gas entry carburetor.

$>$ Operating the Gasifier-engine system with carburetor on HOME and producer gas makes the system completely independent from the use of fossil fuels.

$>$ Dual fuel operation with HOME- producer gas combination resulted in lower performance with increased emission levels compared to Dieselproducer gas operation.

$>$ On an average, for HOME-producer gas operation with parallel flow gas entry carburetor, the BTE was increased by $15.3 \%, 10.67 \%$ and $5.4 \%$ compared to the operation with $\mathrm{Y}$ shape, $60^{\circ}$, and $90^{\circ}$ gas entry carburetors. But it was decreased by $20.4 \%$ compared to Diesel-producer gas operation.

$>$ The smoke opacity for HOME-producer gas operation with parallel flow gas entry carburetor was reduced $24.34 \%, 9.08 \%$ and $4.9 \%$ compared to the operation with $\mathrm{Y}$ shape, $60^{\circ}$, and $90^{\circ}$ gas entry carburetors. Similarly, $\mathrm{HC}$ and $\mathrm{CO}$ emissions were lowered significantly with parallel flow gas entry carburetor compared with other carburetors tested. However, it could be compromised with $27.4 \%, 14.65 \%$ and $5.4 \%$ increased NOx emission levels compared to Y shape, $60^{\circ}$, and $90^{\circ}$ gas entry carburetor operations.

$>$ For HOME-producer gas operation with parallel flow gas entry carburetor, the peak pressure was decreased by $14.4 \%$, $8.32 \%$ and $4.6 \%$ compared to the operation with Y shape, $60^{\circ}$, and $90^{\circ}$ gas entry carburetors.

$>$ Studies on the gasifier-engine system showed that, several new policies towards commercialization and marketization are still necessary, even though India has implemented many policies in renewable energy sector. Some of the reasons for the slow commercialization and marketization are mainly due to high cost of debt. This is the biggest issue facing in renewable energy technology. Hence, to promote Gasifier-Engine system for power production using renewable and alternative fuels, the nation should adopt attractive price setting and good policy. Some of the problems encountered in the implementation of this system and policies can be reduced if government and NGOs initiate the emission reduction and energy plantation programs adequately. 
On the whole, it is seen that dual fuel mode of operation with the selected alternative fuel combination and with different carburetors resulted in lower performance compared to diesel-producer gas operation and smooth engine operation was observed. Among the selected carburetors, HOME-producer gas operation with parallel flow gas entry carburetor resulted in slightly improved performance and decreased smoke, $\mathrm{HC}$ and CO levels compared to the operation with other carburetors tested. Gasifier-Engine systems using renewable fuels with advanced technology are convenient and economically viable. This can serve the future energy needs for transport and agricultural applications.

\section{References}

1. Deepak A., Kumar A. A., 2007. "Performance and Emission Characteristics of a Jatropha Oil (Preheated and Blends) in a Direct Injection Compression Ignition Engine." International Journal of Applied Thermal Engineering 27: 2314-2323.

2. Nwafor O. M. I. 2000. "Effect of Advanced Injection Timing on the Performance of Rapeseed Oil in Diesel Engines." Renewable Energy 21: 433444.

3. Nwafor, O. M. I. 2003. "The Effect of Elevated Fuel Inlet Temperature on Performance of Diesel Engine Running on Neat Vegetable Oil at Constant Speed Conditions." Renewable Energy 28: 171181.

4. Scholl, K. W., Sorenson S. C., 1993. "Combustion Analysis of Soyabean Oil Methyl Ester in a Direct Injection Diesel Engine." Society of Automotive Engineers. Paper No. 930-934.

5. Yaliwal V.S., Nataraja K.M., Banapurmath N.R., Tewari P.G., Honge oil methyl ester and producer gas-fuelled dual-fuel engine operated with varying compression ratios, International Journal of Sustainable Engineering, 2013. DOI: 10.1080/19397038.2013.837108.

6. Khiari K., Awad S., Loubar K., Tarabet L., Mahmoud R., Tazerout M.,
Experimental investigation of pistacia lentiscus biodiesel as a fuel for direct injection diesel engine, Energy Conversion and Management, Volume 108, 15 January 2016, Pages 392-399

7. Senthilkumar S., Sivakumar G., Siddarth Manoharan, Investigation of palm methyl-ester bio-diesel with additive on performance and emission characteristics of a diesel engine under 8-mode testing cycle, Alexandria Engineering Journal, Volume 54, Issue 3, September 2015, Pages 423-428

8. Roy Murari Mohon, Eiji Tomita, Nobuyuki Kawahara, Yuji Harada, Atsushi Sakane. 2009. "Effect of Fuel Injection Parameters on Engine Performance and Emissions of a Supercharged Producer Gas-Diesel Dual Fuel Engine." Society of Automotive Engineers. Paper No. 2009-01-1848.

9. Banapurmath N. R., Yaliwal V. S., Satish Kambalimath, Hunashyal A. M., Tewari P. G., 2011. "Effect of Biomass feed stock, carburetor, Compression Ratio and Biodiesel- Ethanol Blends on the Performance of Dual Fuel Engine." Waste and Biomass Valorization 2 (4): 403-413. doi: 10.1007/s12649- 0119083.

10. Yaliwal V.S., Banapurmath N.R., Gireesh N.M., Tewari P.G., "Production and utilization of renewable and sustainable gaseous fuel for power generation applications: A review of literature". Renewable and Sustainable Energy Reviews, Elsevier publications, 34, 2014, 608-627.

11. Yaliwal V.S., Banapurmath N.R., Gireesh N.M., Hosmath R.S., Teresa Donateo, Tewari P.G., Effect of nozzle and combustion chamber geometry on the performance of a diesel engine operated on dual fuel mode using renewable fuels, Renewable Energy, Elsevier publications, 93, 2016, 483-501.

12. Sridhar G., Sridhar H. V., Dasappa S., Paul P. J., Rajan N. K. S., Mukunda H. S., 2005. "Development of producer gas engines." Proceedings of the Institution 
Mechanical Engineers, Part D: Journal of Automobile Engineering 219: 423-438.

13. Ravindranath N. H., Balachandra P., 2009. "Sustainable Bioenergy for India: Technical, Economic and Policy Analysis." Energy 34: 1003-1013.

14. Nouni M. R., Mullick S. C., Kandpal T. C., 2007. "Biomass Gasifier Projects for Decentralized Power Supply in India: A Financial Evaluation." Energy Policy 35: 1373-1385.

15. Parikh P. P., Bhave A. G., Kapse D. V., Shashikantha S.. 1989. "Study of Thermal and Emission Performance of Small Gasifier-Dual-Fuel Engine Systems." Biomass 19: 75-97.

16. Ramadas A. S., Jayaraj S., Muralidharan C.. 2006. "Power Generation Using Coir Pith and Wood Derived Producer Gas in a Diesel Engine." Fuel Processing Technology 87: 849-853.

17. Singh R. N., S. P. Singh, and B. S. Pathak. 2007. "Investigations on Operation of CI Engine Using Producer Gas and Rice Bran Oil in Mixed Fuel Mode." Renewable Energy 32: 15651580.

18. Vinay Shrivastava, Abhishekh Kumar Jha, Arun Kumar Wamankar and S. Murugan, Performance and emission studies of a CI engine coupled with gasifier running in dual fuel mode, Chemical, Civil and Mechanical Engineering. Tracks of 3rd Nirma University. International Conference on Engineering (NUiCONE 2012), Procedia Engineering, Elsevier publication, Vol. 51, 2013, pp $600-608$.

19. Anil T.R., Ravi S.D., Shashikanth M., Rajan N.K.S., Tewari P.G., 2006. CFD Analysis of a Mixture Flow in a Producer Gas Carburetor, International Conference On Computational Fluid Dynamics, Acoustics, Heat Transfer and Electro-magnetic. CFEMATCON-06, July 24-25. Andhra University, Visakhapatnam - 530003, INDIA.

20. Vinay S.S., Ravi S.D., PremaKumar G., Rajan N. K.S., 2008. Numerical and Experimental Modeling of Producer Gas
Carburettor, Proc. of the International Conference on Advances in Mechanical Engineering, S.V. National Institute of Technology, Surat, Gujarat, India, pp 1 9.

21. Roussos G. Papagiannakis and Dimitrios T. Hountalas, The Impact of Total Equivalence Ratio on Environmental Behavior of a Natural Gas Dual Fuel Diesel Engine, International journal of energy and environment, 5(6), 2011 733744. 